\title{
EDITORIAL
}

\section{Bringing everyone on board: what role can medical students play in the COVID-19 pandemic?}

\author{
Izabel C. Rios ${ }^{1}$, Marina Alves Martins Siqueira', Matheus Belloni Torsani', \\ Rosemeire K. Hangai ${ }^{1}$, Solange R. G. Fusco ${ }^{1}$, Aluisio C. Segurado ${ }^{1,2}$ for the \\ Hospital das Clinicas COVID-19 Crisis Management Committee ${ }^{2}$
}

The fast spread of the COVID-19 epidemic has imposed unprecedented challenges to contemporary society, impacting several aspects of human life globally. Strict social distancing protocols had to be implemented in affected countries to contribute to reduce viral dissemination, and consequently, limit acquisition of new infections. Health systems were compelled to put emergency plans in place to cope with the overburden of potentially severe cases needing hospitalization, with the ultimate aim to preserve as many lives as possible. Academic health systems worldwide were required to propose novel strategies to maximize healthcare outcomes while mitigating negative impact on medical education.

In this scenario, Faculdade de Medicina da Universidade de São Paulo (FMUSP) and its affiliated Hospital das Clinicas (HCFMUSP) were no exception to the rule. Located in the city of São Paulo, the epicenter of the Brazilian epidemic, our academic health center launched institutional initiatives to meet the needs of scaling up healthcare provision to a large number of patients with severe COVID-19 in a designated hospital building (Instituto Central). In parallel, actions were taken to keep the medical curriculum active, using technological tools to support online distance learning to students in their preclinical and clinical stages of education.

A particular concern in this environment was to determine to what extent medical students should be summoned or, alternatively, invited to integrate institutional efforts in response to the epidemic. Ensuring safety and supporting their doubts and anxieties having to face the unpredictable course of a potentially life-threatening contagious disease was crucial. We were confronted with the ethical dilemma of either "doing no harm", keeping medical students away from clinical settings where interaction with COVID-19 patients was expected, or responding to their willingness to contribute somehow in such a dramatic public health scenario.

Experience from foreign countries which had been previously stricken by the pandemic is diverse and sometimes contradictory. In the UK and Ireland, for instance, final year medical students were allowed to act as

\footnotetext{
1.Hospital das Clinicas, Faculdade de Medicina, Universidade de São Paulo. ORCID: Rios IC - https://orcid.org/0000-0002-0241-4421; Siqueira MAM - https://orcid.org/0000-0001-7394-1010; Torsani MB - https://orcid.org/0000-0002-6630-9495; Hangai RK - https:// orcid.org/0000-0001-6645-1443; Fusco SRG - https://orcid.org/0000-0002-1243-1743; Segurado AC - https://orcid.org/0000-00026311-8036. Emails: izabel.rios@fm.usp.br, marina.siqueira@fm.usp.br, solange.fusco@hc.fm.usp.br, rosemeire.hangai@hc.fm.usp. br, aluisio.segurado@fm.usp.br.

2.Authorship - Hospital das Clinicas COVID-19 Crisis Management Committee: Beatriz Perondi, Anna Miethke-Morais, Amanda C. Montal, Leila Harima, Danielle P. Moraes, Marcelo R. Azevedo, Lucila Pedroso, Marcelo C, Rocha, Marjorie F. Silva, Tarcísio E. Pessoa de Barros-Filho, Edivaldo Utiyama and Eloisa Bonfá.
} 
doctors, working closely in multi-professional teams involved in COVID-19 care, and were accordingly given credit for gaining experience and providing service ${ }^{1}$. Likewise, students at the Aalborg University Hospital in Denmark were kept rotating in clinical placements after completing fast-track training courses in nursing assistance and mechanical ventilation ${ }^{2}$. Italian authorities went further and issued recommendations for an expedited graduation in medical schools to help strengthen the health professional workforce for the emergency ${ }^{3}$. In contrast, the American Association of Medical Colleges (AAMC) explicitly declared concern about engaging students in the response to the pandemic due to the risk for infection to patients and students, the impact students might cause to personal protection equipment (PPE) stocks in a context of possible shortages, or based on liability issues ${ }^{4,5}$.

In this article we describe how FMUSP students were invited to contribute to the institutional response to the pandemic, taking responsibilities within their level of competence, depending on previously acquired skills and willingness to participate. Starting on March 30, 2020, a 900-bed facility of our HCFMUSP complex (Instituto Central) was exclusively designated for inpatient care of suspected and confirmed cases of COVID-19, admitted after referral by a state-wide centralized system. Inpatients with other clinical conditions were transferred to other institutes within the complex and the emergency room moved to the Heart Institute (InCor). Final year medical students under clinical rotations in emergency services started to work in these recently rearranged facilities, sites regarded as of low exposure to coronavirus infection, being thus able to continue their regular scheduled internship program.

However, students in their $5^{\text {th }}$ year of medical school, who at that time were involved in clinical care in wards originally located at the Central Institute or performed at the outpatient clinic next door, had their programs discontinued. The sharp reduction in number of beds for patients not infected with coronavirus in the newly allocated institutes, and of medical visits to the outpatient clinic hindered continuation of these clinical activities. In parallel, students in their first 4 years of medical education had their in-person lectures discontinued and teaching programs entirely shifted to online distance learning activities.

At this point the institutional plan was to keep students off the frontline, considering the need to avoid their infection with coronavirus, the overburden professionals directly involved in COVID-19 care would experience that would certainly limit their tutorial capacity in supervising students in patient-contact clinical settings, as well as the need to spare PPE for professionals actually in charge. Nevertheless, we realized the opportunity to bring students on board in this exceptional epidemic scenario should not be missed. As highlighted by Kalet et al. ${ }^{6}$, enabling safe and effective deployment of students in the clinical arena in this unique moment should be our responsibility as medical educators, in clear demonstration of civic, moral, and educational duty.

Bearing this in mind, academic staff members working for the institutional Center for Humanization of Healthcare (Núcleo Técnico de Humanização - NTH) in partnership with the COVID-19 Crisis Management Committee conceived a comprehensive portfolio of activities students could voluntarily undertake (Table 1), addressing different needs of patients with COVID-19, their families, healthcare personnel or being related to other academic pillars of our mission, such as health education and clinical research. An application platform was created, describing the specific aims, students' requirements and detailed duties expected from participants of each activity for students to identify what suited them best.

After 2 months in operation, we can conclude our results are largely encouraging: 297 students applied to take part in at least one of the several offered initiatives and 68 are already actively engaged. In a feedback survey, carried out by FMUSP Center for Development of Medical Education (Centro de Desenvolvimento de Educação Médica - CEDEM), students recognized volunteering during the pandemic as a path to academic and personal development.

In fact, the platform gave our student body the opportunity to engage in a broad variety of activities during these hard times, contributing to the development of their professional identity. Having experienced this unprecedented pandemic during their professional education will indeed mark their lives forever. As proposed by Cruess et al. ${ }^{7}$, this was their chance to demonstrate, in different ways, altruism, courage, dedication to patients, having been there to help ease the suffering of many. We believe it definitely helped them "start thinking, acting, and feeling like a physician" 7 . 
Table 1. Portfolio of activities offered to volunteer undergraduate students during the COVID-19 epidemic. Hospital das Clinicas, São Paulo, Brazil, 2020

\begin{tabular}{|c|c|c|c|}
\hline Activity & Aims & Actions & $\begin{array}{l}\text { Eligible students and } \\
\text { partners }\end{array}$ \\
\hline Health education & $\begin{array}{l}\text { To establish a communication } \\
\text { platform for the general } \\
\text { public with information about } \\
\text { COVID-19 }\end{array}$ & $\begin{array}{l}\text { Development of the "Portal COVID" } \\
\text { web platform }\end{array}$ & Medical students \\
\hline \multirow{3}{*}{$\begin{array}{l}\text { Support to } \\
\text { clinical care }\end{array}$} & $\begin{array}{l}\text { To screen outpatients for } \\
\text { COVID-19 symptoms }\end{array}$ & $\begin{array}{l}\text { Application of a standardized } \\
\text { questionnaire on COVID-19 symptoms } \\
\text { and temperature assessment of patients } \\
\text { entering the outpatient clinic }\end{array}$ & $\begin{array}{l}\text { Medical students and nursing* } \\
\text { students }\end{array}$ \\
\hline & $\begin{array}{l}\text { To connect in-patients with their } \\
\text { families during hospitalization } \\
\text { when they cannot use their own } \\
\text { communication devices }\end{array}$ & $\begin{array}{l}\text { Conducting virtual visits with patients } \\
\text { in the wards and their loved ones using } \\
\text { tablets and wifi access }\end{array}$ & Medical students and HCW \\
\hline & $\begin{array}{l}\text { To assist inpatient care for non } \\
\text { COVID-19 patients }\end{array}$ & $\begin{array}{l}\text { Integration into inpatient } \\
\text { multiprofessional healthcare teams } \\
\text { in recently reassigned wards(in low } \\
\text { exposure Institutes) }\end{array}$ & $\begin{array}{l}5^{\text {th }} \text { and } 6^{\text {th }} \text { year medical students } \\
\text { (internship program) }\end{array}$ \\
\hline \multirow{2}{*}{$\begin{array}{l}\text { Caring for } \\
\text { frontline } \\
\text { caregivers }\end{array}$} & $\begin{array}{l}\text { To offer physical activities for } \\
\text { frontline HCW }\end{array}$ & $\begin{array}{l}\text { Conducting programmatic workouts } \\
\text { as part of a program of mental health } \\
\text { support to healthcare workers }\end{array}$ & Medical students \\
\hline & $\begin{array}{l}\text { To produce audio and video } \\
\text { registers of patients and } \\
\text { healthcare teams at work in } \\
\text { wards }\end{array}$ & $\begin{array}{l}\text { Production of videos, photos and } \\
\text { messages to HCW when patients are } \\
\text { discharged from the hospital }\end{array}$ & Medical students \\
\hline \multirow{4}{*}{ Clinical research } & $\begin{array}{l}\text { To investigate biomarkers of } \\
\text { inflammation among COVID-19 } \\
\text { patients upon admission to the } \\
\text { ER }\end{array}$ & $\begin{array}{l}\text { Data collection on clinical and } \\
\text { laboratory parameters at admission to } \\
\text { the ER }\end{array}$ & $5^{\text {th }}$ year medical students \\
\hline & $\begin{array}{l}\text { To assess clinical outcomes } \\
\text { among patients on mechanical } \\
\text { ventilation }\end{array}$ & $\begin{array}{l}\text { Data collection on clinical parameters } \\
\text { of patients under intensive care and } \\
\text { mechanical ventilation }\end{array}$ & $\begin{array}{l}\text { Medical, physioterapy and } \\
\text { nursing students }\end{array}$ \\
\hline & $\begin{array}{l}\text { To use a telecommunication } \\
\text { platform for patients to interact } \\
\text { with families at time of discharge } \\
\text { from hospital }\end{array}$ & $\begin{array}{l}\text { Use of tablets to allow family members } \\
\text { watch the moment patients are being } \\
\text { released from wards celebrating } \\
\text { recovery }\end{array}$ & $\begin{array}{l}\text { Medical student, nursing } \\
\text { students and multi-professional } \\
\text { residents (hospital management } \\
\text { and social work) and HCW }\end{array}$ \\
\hline & $\begin{array}{l}\text { To screen frontline healthcare } \\
\text { personnel for COVID-19 } \\
\text { antibodies }\end{array}$ & $\begin{array}{l}\text { Application of a standardized } \\
\text { questionnaire in search of } \\
\text { sociodemographic data and risk } \\
\text { factors for exposure to SARS-CoV-2 } \\
\text { or development of severe COVID-19 }\end{array}$ & $4^{\text {th }}$ and $5^{\text {th }}$ year medical students \\
\hline Fund raising & $\begin{array}{l}\text { To raise funds from societal } \\
\text { partners to support enhanced } \\
\text { expenditures during the } \\
\text { pandemic }\end{array}$ & $\begin{array}{l}\text { Development of a social media platform } \\
\text { ("Vem prá Guerra") for fund raising }\end{array}$ & Medical students and residents \\
\hline $\begin{array}{l}\text { Project } \\
\text { management }\end{array}$ & $\begin{array}{l}\text { To contribute for project } \\
\text { management - Center for } \\
\text { Humanization of Healthcare }\end{array}$ & $\begin{array}{l}\text { Development of process flowcharts and } \\
\text { contents driven to leaders about how to } \\
\text { manage teams in times of crisis }\end{array}$ & $\begin{array}{l}\text { Medicina Jr. start-up company } \\
\text { participants }\end{array}$ \\
\hline
\end{tabular}

HCW - healthcare workers, ER - emergency room.*Nursing students were recruited at Escola de Enfermagem da USP 
Rios IC. Bringing everyone on board: what role can medical students play in the COVID-19 pandemic?

Acknowledgements: The authors are grateful to Profs. Regina Szylit and Maria de Fátima F. Vattimo for the partnership that enabled participation of nursing students from Escola de Enfermagem da USP in some of the cited projects.

\section{REFERENCES}

1. DeWitt DE. Fighting COVID-19: enabling graduating students to start internship early at their own medical school. Ann Inter Med. 2020 Apr 7:M20-1262. doi: 10.7326/M20-1262.

2. Rasmussen S, Sperling P, Poulsen MS, Emmersen J, Andersen S. Medical students for health-care staff shortages during the COVID-19 pandemic. Lancet. 2020 May 2;395(10234):e79-e80. doi: 10.1016/S0140-6736(20)30923-5.

3. Wang JH, Tan S, Raubenheimer K. Rethinking the role of senior medical students in the COVID-19 response. Med J Aust. 2020 May 5. doi:10.5694/mja2.50601.

4. Miller DG, Pierson L, Doernberg S. The role of medical students during the COVID-19 pandemic. Ann Intern Med. 2020 Apr 7:M20-1281. doi:10.7326/M20-1281.

5. Whelan A, Prescott J, Young G, et al. Guidance on medical students' clinical participation: effective immediately. Association of American Medical Colleges, 17 March 2020 [cited 2020 June 5]. Available from: https://cme.org/wp-content/uploads/ filebase/March-17-2020-Guidance-on-Mediical-Students-Clinical-Participation.pdf.

6. Kalet AL, Jotterand F, Muntz M, Thapa B, Campbell B. Hearing the call of duty; what we must do to allow medical students to respond to the COVID-19 pandemic. WMJ. 2020;119(1):6-7. Available from: https://wmjonline.org/wp-content/ uploads/2020/119/1/6.pdf.

7. Cruess RL, Cruess SR, Boudreau D, Snell L, Steinert Y. Reframing medical education to support professional identity formation. Acad Med. 2014;89:1146-51. doi: 0000000000000427. 